\title{
Working
}

Paper 




\title{
Walking Hand in Hand: Fiscal Policy and Growth in Advanced Economies
}

\author{
Carlo Cottarelli and Laura Jaramillo
}




\title{
IMF Working Paper
}

Fiscal Affairs Department

\section{Walking Hand in Hand: Fiscal Policy and Growth in Advanced Economies ${ }^{1}$ Prepared by Carlo Cottarelli and Laura Jaramillo}

May 2012

\section{This Working Paper should not be reported as representing the views of the IMF.} The views expressed in this Working Paper are those of the author(s) and do not necessarily represent those of the IMF or IMF policy. Working Papers describe research in progress by the author(s) and are published to elicit comments and to further debate.

\begin{abstract}
Implementation of fiscal consolidation by advanced economies in coming years needs to take into account the short and long-run interactions between economic growth and fiscal policy. Many countries must reduce high public debt to GDP ratios that penalize longterm growth. However, fiscal adjustment is likely to hurt growth in the short run, delaying improvements in fiscal indicators, including deficits, debt, and financing costs. Revenue and expenditure policies are also critical in affecting productivity and employment growth. This paper discusses the complex relationships between fiscal policy and growth both in the short and in the long run.
\end{abstract}

JEL Classification Numbers: E43, E62, H30, O40

Keywords: Government debt, budget deficit, growth, advanced economies, sovereign spreads Author‘s E-Mail Address:ccottarelli@imf.org; 1jaramillomayor@imf.org

\footnotetext{
${ }^{1}$ A preliminary draft of this paper was presented at the Collegio Carlo Alberto of Turin on March 17, 2012, and the Catholic University of Milan on March 18, 2012. We would like to thank the participants in those presentations for their helpful comments. We would also like to thank Olivier Blanchard, Antonio Spilimbergo, Michael Goldby, Philip Gerson, and Martine Guerguil for their useful comments on the econometric analysis. We also thank Raquel Gomez Sirera for excellent research assistance.
} 


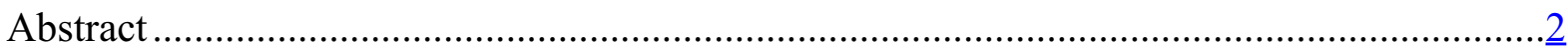



II. Short-run interactions between growth and fiscal policy .................................................

III. Long-term interactions between growth and fiscal policy................................................

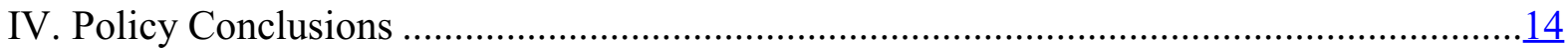

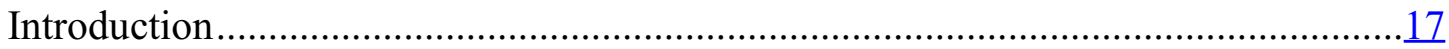

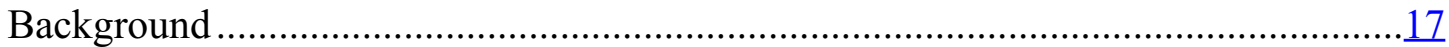

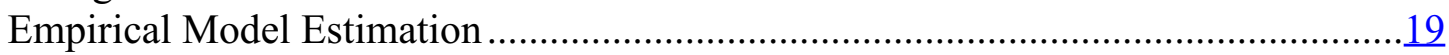

Estimation Results .............................................................................................



\section{Table}

1. Determinants of CDS Spreads in Advanced Economies, Cross Section Analysis 2011 ........ $\underline{8}$

\section{Figures}

1. Historical Public Debt..................................................................................................

2. Impact on the Deficit to GDP of a 1 Percent of GDP Discretionary Fiscal Tightening in the First Year Relative to Baseline .................................................................................

3. Impact of the Debt Ratio of a 1 Percent of GDP Discretionary Fiscal Tightening in

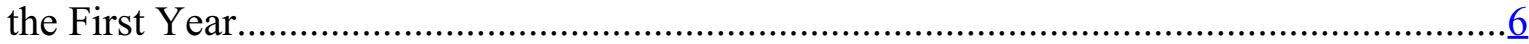

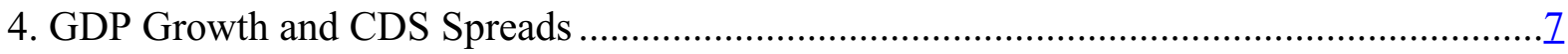

5. Fiscal Adjustment and CDS Spreads with Alternative Fiscal Multipliers.............................. $\underline{8}$

6. Effect on Growth of Higher Debt to GDP Ratio..............................................................

7. Potential Revenue Increases in Advanced G7 Countries...................................................11

8. Public Sector Wages in Selected G7 Countries .........................................................12

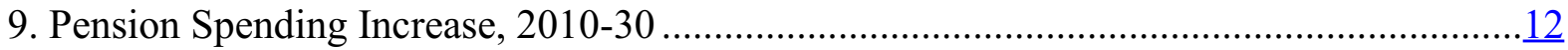

10. Long-term Average of Primary Balance and Real GDP Growth .....................................14

11. Effect of Growth on Debt Stabilizing Primary Surplus ....................................................

\section{Appendix}

Short-run Determinants of CDS Spreads in Advanced Economies ........................................17

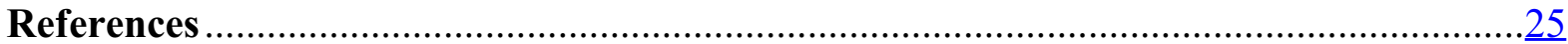




\section{INTRODUCTION}

The relationship between economic growth and fiscal policy is complex and is of critical importance for policymakers in advanced countries. It is complex because of the various kinds of feedback loops between one and the other. Fiscal policy has critical implications for economic growth both in the short and the long run. At the same time, strong growth greatly facilitates fiscal adjustment, both in the short and over the long run. Policymakers need to be aware of this interaction as sizeable fiscal adjustment is needed in most advanced countries over the coming years in order to bring down the debt to GDP ratio, which has reached a historical peak seen only once in the last 130 years (Figure 1).

This paper discusses the feedback loops between fiscal policy and growth. It argues that stabilizing public debt-to-GDP at current levels penalizes potential growth, which in turn would make it more difficult to sustain high public debt over the longer run. Therefore, it is imperative to lower public debt over time. However, in the short-run, front-loaded fiscal adjustment is likely to hurt growth prospects, which

Figure 1. Historical Public Debt to GDP (Percent)

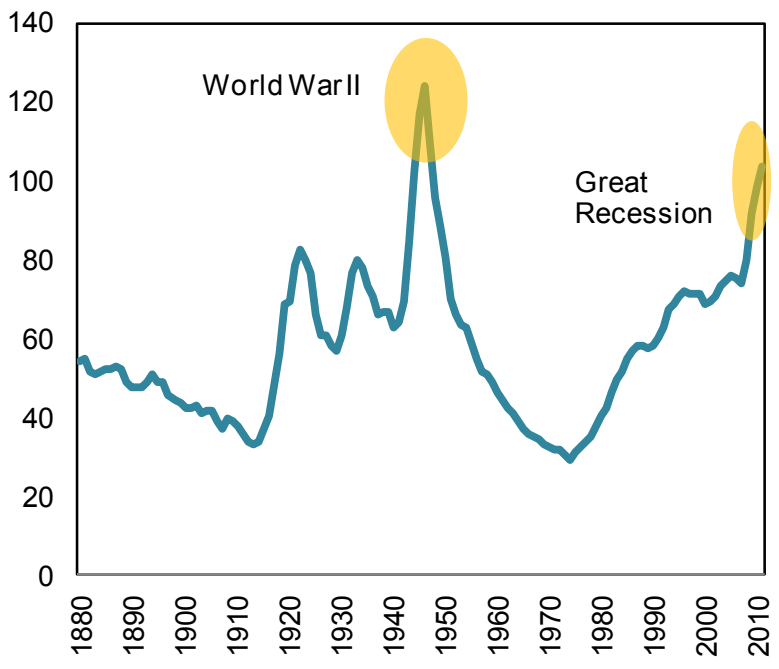

Source: IMF Historical Public Debt Database would delay improvements in fiscal indicators, including deficits, debt, and financing costs. A measured, although not trivial, pace of adjustment, based on a clear medium-term plan, is therefore preferable, if market conditions allow it. The recognition that, other conditions being the same, fiscal adjustment will slow down growth, makes it important to ensure that other policies (monetary, financial, and structural policies) are used to support growth when fiscal policy is tightened. The paper goes on to discuss the importance of strong mediumterm growth for a successful fiscal consolidation. Reforms in goods, service, and labor markets that improve economic efficiency will boost potential growth, in turn serving as important tools in the fiscal adjustment process.

Section II discusses the short-term interactions between growth and fiscal policy. Section III focuses on the longer-term interactions. Section IV draws policy conclusions for both the short and the long term.

\section{SHORT-RUN INTERACTIONS BETWEEN GROWTH AND FISCAL POLICY}

Fiscal adjustment affects growth in the near term through two main channels. First, by strengthening the fiscal accounts, fiscal adjustment enhances fiscal sustainability, thereby 
reducing the risk of a fiscal crisis. The turbulence recently faced by euro area countries with weak fiscal accounts is a reminder of the importance of this channel. A weak fiscal position is certainly not a sufficient condition to be under market pressure, but it is a necessary condition. This is confirmed by recent studies looking at sovereign bond yields since the onset of the global crisis, which find that, while global risk aversion is a key determinant, fiscal fundamentals have played an increasingly important role. Sgherri and Zola (2009) suggest that, while euro area sovereign risk premium differentials tend to commove over time and are mainly driven by a common time-varying factor, markets have become progressively more concerned about fiscal fundamentals. Similarly, Haugh et al. (2009) find that the increase in global risk aversion has magnified the importance of fiscal performance in several euro area countries, and these effects are non-linear, so that the incremental deteriorations in fiscal performance lead to even larger increase in the spread. Schuknecht et al. (2010) also find that markets penalize fiscal imbalances much more strongly after the Lehman default in 2008. In addition, Caceres et al. (2010) show that earlier in the crisis the surge in global risk aversion was a significant factor influencing sovereign bond spreads, while more recently public debt and deficits have started playing a more important role.

The second channel through which fiscal adjustment affects growth is its negative effect on aggregate demand. While consensus around the standard Keynesian view that fiscal policy has an important role to play in mitigating the business cycle had developed in the aftermath of the Great Depression, ${ }^{2}$ by the 1990s many economists rejected discretionary fiscal policy as an effective stabilization tool. ${ }^{3}$ Some have even argued that "expansionary fiscal contractions" exist, especially if fiscal tightening is focused more on spending cuts rather than tax increases. ${ }^{4}$ The recent global crisis has led economists to once again reevaluate this view. While indeed there have been cases in which a sharp tightening of fiscal policy has been accompanied by an economic expansion, Perotti (2011) shows that this output expansion typically reflects exchange rate depreciation and a relaxation of monetary conditions rather than confidence effects per se arising from fiscal tightening. Thus, in the absence of an independent exchange rate or monetary policy — which is the case of euro area countries-fiscal consolidation is likely to be accompanied by lower economic growth. Evidence provided by IMF (2010a) shows that fiscal multipliers during fiscal contractions are likely to be positive on average, even with an independent monetary policy. Furthermore, much of the literature measuring the magnitude of fiscal multipliers has ignored that standard

\footnotetext{
${ }^{2}$ See Hall, ed. (1989)

${ }^{3}$ See Feldstein (2002) for a discussion of main factors that explain economists` questioning of the Keynesian view.

${ }^{4}$ Empirical evidence in support of the expansionary fiscal contraction hypothesis (which argues that large fiscal consolidations lead to a revision in expectations about the future tax burden and may also induce a supply-side response if taxes are distortionary) was provided by Bertola and Drazen (1993), Alesina and Perotti (1996), Sutherland (1997), Perotti (1999), and, more recently, Alesina and Ardagna (2009).
} 
economic theory implies that fiscal multipliers should be larger when output is below potential (because when the output gap is closed or positive, a fiscal expansion will result in more inflation or external deficits, not more output). The evidence in Baum et al. (2012) confirms this view. Finally, with interest rates at already very low levels in several advanced economies, the effects on growth of a fiscal tightening are likely to be larger now than in comparable cyclical phases where monetary policy can play a larger role.

Fiscal policy must therefore take into account the effect of these two opposing channels (the first pointing at the output cost of pursuing fiscal adjustment without sufficient vigor, the second pointing at the output costs of excessive fiscal zeal) and strike the right balance, as argued in IMF (2012a and 2012b).

Some could make the case that a short-term deceleration in economic activity is the price to pay to strengthen public finances and, therefore, avoid even bigger problems later on. However, this view does not take into account the feedback from growth to the fiscal accounts, which could potentially delay, or even nullify, the expected gains.

Growth impacts the fiscal accounts through three main channels. First, a deceleration of growth triggers automatic stabilizers, which reduce tax revenues and increase welfare spending (such as unemployment benefits). ${ }^{5}$ This implies that, if fiscal policy is tightened by, say, one percentage point of GDP, the actual improvement of the overall deficit is smaller by an amount that depends on the size of automatic stabilizers (as well as on the fiscal multiplier). Figure 2 illustrates for various countries the relationship between discretionary tightening and the actual decline in the deficit-to-GDP ratio taking into account the operation of the automatic stabilizers, and assuming a fiscal multiplier of 1 with respect to the initial discretionary tightening. On average for advanced economies, a one percentage point of GDP discretionary tightening leads to 0.7 percentage point reduction in the deficit. Therefore, while the deficit does decline, it does so by less than the discretionary tightening.

Second, a deceleration of growth prompted by a fiscal consolidation could result in a rise in the government debt-to-GDP ratio. This is found to be the case if the initial stock of debt is large and the fiscal multiplier is high. The effect of fiscal tightening on debt (the numerator of the ratio) in percentage terms is smaller the higher the initial stock of debt to GDP. Meanwhile, the negative effect of fiscal tightening on GDP (the denominator of the ratio) is larger the higher the fiscal multiplier.

\footnotetext{
${ }^{5}$ For a comparison of automatic stabilizers in Europe and the United States in the context of the global crisis, see Dolls et al. (2010).
} 
Figure 2. Impact on the Deficit to GDP of a 1 percent of GDP Discretionary Fiscal Tightening in the First Year Relative to Baseline

(Percent of GDP)

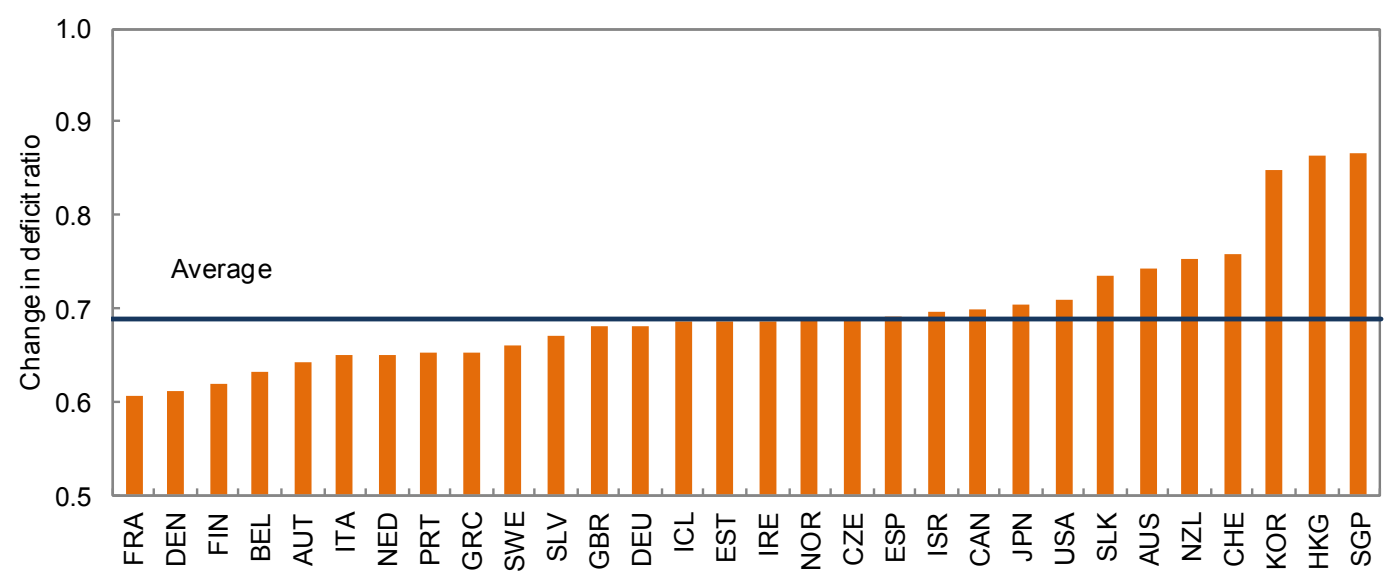

Note: Assumes a fiscal multiplier of 1.

Source: IMF Fiscal Monitor and authors' calculations.

Figure 3 identifies the cases in which the debt ratio is likely to rise with a one percentage point discretionary tightening (Eyraud and Weber, 2012). While this effect is likely to be short-lived-beyond the first year, the debt ratio would start declining as the deficit moves to a permanently lower level, while GDP stops declining - it could generate a negative market response if financial markets focus on the short-run behavior of the debt ratio. Moreover, the debt ratio may continue rising for longer if a country implements repeated sequential fiscal tightening.

Third, a deceleration of growth prompted by a fiscal consolidation could trigger nervousness in financial markets. Given a certain debt and deficit ratio, higher growth countries typically see lower financing costs, because these countries are perceived to be able to "grow out" of their debt and therefore represent lower



Source: Eyraud and Weber (2012) credit risk. ${ }^{6}$ In principle, long-term growth is what matters to ensure fiscal sustainability. However, in practice, markets seem to have been focusing recently on short-term growth

\footnotetext{
${ }^{6}$ For example, the three major credit rating agencies (Standard and Poor's, Moody's, and Fitch Ratings) all include real GDP growth as an important factor in their analysis of credit worthiness.
} 
developments. ${ }^{7}$ Figure 4 shows a negative correlation between growth in 2011 and credit default swap (CDS) spreads, while there seems to be no relationship between spreads and potential growth. This focus by financial markets on short-term growth could be explained by political economy considerations (markets may believe that a country facing a sizeable decline in GDP is unlikely to sustain its fiscal adjustment effort over time), or it may be simply due to some degree of short-termism by market agents following several years of heightened market uncertainty.

Figure 4. GDP Growth and CDS Spreads


Sources: Markit, and IMF (2010b)

Financial markets' concern with short-run growth in recent times is confirmed by econometric results displayed in Table 1 (discussed in further detail in the appendix). In 2011, fiscal fundamentals (primary balances and public debt) were found to have a significant effect on CDS spreads in advanced economies: an improvement in the primary balance-to-GDP ratio would reduce spreads while an increase in debt to GDP would raise them. Short-term growth is also found to be a significant factor, and its effect is non-linear. The signs of the coefficients on growth and growth squared imply not only that spreads increase as growth falls, but also that the increase in spreads per unit of decline in GDP is larger the lower the initial growth rate. This implies that markets get increasingly worried as growth enters low or negative territory. Based on this regression, Figure 5 illustrates how spreads would behave with different sizes of fiscal adjustment, taking into account the negative effect of fiscal adjustment on growth (i.e., different fiscal multipliers) both directly and through its effect on the debt ratio. If the fiscal multiplier is sufficiently high and if fiscal tightening is sufficiently large, consolidation is accompanied by higher, not lower, spreads.

\footnotetext{
${ }^{7}$ See Escolano (2010), as well as Section III below.
} 
Table 1. Determinants of CDS Spreads in Advanced Economies, Cross Section Analysis 2011

\begin{tabular}{lc}
\hline Determinant & Coefficient \\
\hline Gross debt to GDP 2011 & $0.0122^{\star * *}$ \\
& $(2.931)$ \\
Primary balance to GDP 2011 & $-0.194^{\star * *}$ \\
for Euro Area & $(-3.800)$ \\
& $-0.230^{\star * \star}$ \\
Real GDP growth 2011 & $(-3.860)$ \\
& $0.0323^{* *}$ \\
Real GDP growth squared & $(2.545)$ \\
& \\
Debt held by a country's central bank or & $-0.0272^{*}$ \\
by foreign central banks to GDP & $(-1.842)$ \\
& $0.222^{\star * *}$ \\
Inflation rate 2011 & $(2.907)$ \\
Constant & $3.490^{* * *}$ \\
& $(7.495)$ \\
Observations & 31 \\
R-squared & 0.760 \\
\hline
\end{tabular}

Robust t-statistics in parentheses

${ }^{* * *} p<0.01,{ }^{* *} p<0.05,{ }^{*} p<0.1$
Figure 5. Fiscal Adjustment and CDS Spreads with Alternative Fiscal Multipliers

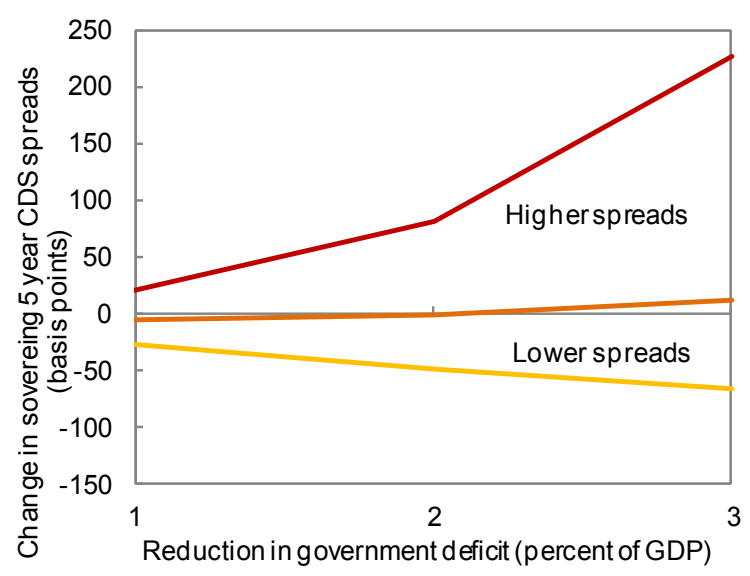

- Fiscal multiplier of 1.0

Fiscal multiplier of 0.7

- Fiscal multiplier of 0.1

\begin{abstract}
Sources: Authors' calculations.
Note: The chart is based on a rep resentative country with a debt to GDP ratio of 100 percent, a p rimary deficit of 3.5 percent of GDP, and an nual GDP growth of 1.5 percent. Each line represents the relationship between adjustment and sp reads based on a different assumption about the multiplier forspending (i.e., the impact of discretionary fiscal tightening on growth, from a smaller to larger impact on growth), ran ging from 0.1 to 1.0 . A larger multiplier weakens-or even fully reverses for larger adjustments the impact of lower deficits and debt on CDS spreads.
\end{abstract}

The possible increase in spreads when fiscal policy is tightened creates a problem for upholding a fiscal adjustment strategy, not only because higher financing costs increase the overall deficit, but also because of political economy reasons. If painful fiscal tightening is accompanied by early evidence of an improvement in credibility, the adjustment is more easily sustained, but if markets do not reward the effort, the resolve of the government to carry on the fiscal adjustment may be undermined.

\section{LONG-TERM INTERACTIONS BETWEEN GROWTH AND FISCAL POLICY}

Let us consider first the effect that fiscal policy has on potential growth. These effects operate both through macroeconomic and microeconomic channels.

A key macroeconomic channel is the effect of high public debt on potential growth. Kumar and Woo (2010), Reinhart and Rogoff (2010), and Cecchetti et al. (2011) all find that beyond a certain threshold - about 80-90 percent of GDP - higher public debt lowers potential 
growth. ${ }^{8}$ High debt is expected to result in lower growth because of crowding out effects on private investment, which would thereby lower productivity growth. Italy and Japan, two high-debt/low-growth countries, are good examples of this effect. Figure 6 illustrates this relationship based on Kumar and Woo (2010), who find that an increase by 10 percentage points of the debt to GDP ratio lowers potential growth by about 0.17 percent. This implies a percentage point of GDP difference in potential growth between having a debt of 120 percent of GDP and a debt of 60 percent of GDP. With the crisis, the share of GDP produced by countries with a debt-to-GDP ratio above 80 percent increased from 19 percent of GDP in 2007 to 81 percent in 2011, which raises the concern that advanced countries will see slower potential growth if

Figure 6. Effect on Growth of Higher Debt to GDP Ratio

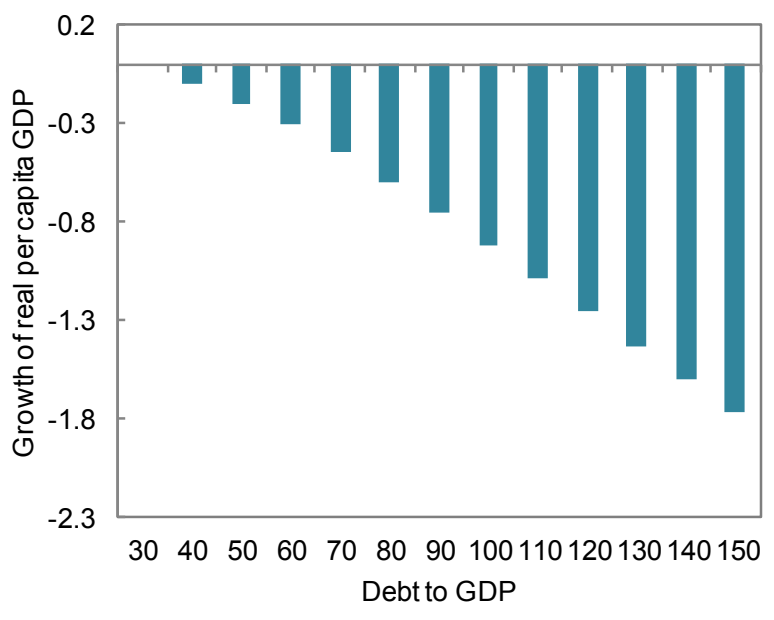

Source: Kumar and Woo (2010). debt is not brought down over the medium term.

The microeconomic effects of fiscal policy on growth are those related to the way the presence of the public sector is felt in the economy above and beyond its macroeconomic balances (deficit and debt). The overall tax pressure, how tax revenues are levied, and the manner in which spending takes place all affect economic incentives and hence investment, employment, economic efficiency and growth. There are also trade offs. For example, public policies that tend to be less distortionary enhance economic efficiency. They may, however, not be conducive to a more equitable income distribution, which many argue is necessary for growth to be sustainable, as revealed by recent events in Middle East. ${ }^{9}$

It is therefore critical that the tools used to implement fiscal adjustment are selected taking into account their effects on potential growth. Estimates by IMF staff show that it would be possible to raise revenues by 3 percentage points of GDP on average in advanced countries, through tax measures that could actually improve economic efficiency (or that at least would be less distortionary than others). This would involve a combination of cuts in tax

\footnotetext{
${ }^{8}$ Kumar and Woo (2010) find that higher debt starts affecting growth at a lower threshold (40 percent of GDP), but the effects become statistically significant only at about 90 percent of GDP. However, Panizza and Presbitero (2012) do not find evidence of an effect of public debt on medium-term growth.

${ }^{9}$ For example, Berg and Ostry (2011) find that longer growth spells are robustly associated with more equality in the income distribution.
} 
expenditure, externality-reducing taxation, property taxation and reduction in tax evasion (Figure 7). In particular:

- $\quad$ Economic growth would benefit from lower contribution rates when the overall tax pressure (as measured by the tax to GDP ratio) is already high - as is the case in continental Europe. ${ }^{10}$ At the same time, in countries where tax pressure is relatively low-like Japan and the United States - the magnitude of the existing fiscal imbalances is such that addressing it just through spending measures would likely require cutting not only nonproductive spending but productive spending as well. Indeed, a recent paper by Baldacci et al. (2012) shows that fiscal adjustment that relies only on spending cuts is less successful when the adjustment need is large.

- When it comes to the composition of revenues, taxing consumption leads to lower distortions than taxing income. In particular, countries that are facing competitiveness problems can benefit from "fiscal devaluation," that is, shifting from labor taxation to consumption (or property) taxation as a way to mimic a nominal devaluation. De Mooij and Keen (2012) show that the effects of a "fiscal devaluation" on growth are larger in the short than in the long run. However, a fiscal devaluation can have stronger effects on growth when, as a result of nominal wage rigidity, it leads to a decline in real wages from a disequilibrium position.

- $\quad$ Eliminating tax expenditures - provisions in the tax code that provide preferential treatments of certain sectors or activities - are a good way of raising revenues while reducing distortions. An example of tax expenditures is the existence of multiple VAT rates. Their abolition is highly controversial, as lower rates typically apply on goods and services believed to be consumed more by the poor, like food and clothing. However, while these goods as a percentage of income are consumed more by the poor, in absolute terms they are consumed more by the wealthy. Therefore, by eliminating these lower VAT tax rates it would be possible to raise revenues in a way that allows not only a reduction in the deficit but also an increase in direct support to the poor through targeted spending.

- $\quad$ Some taxes should be raised in order to correct externalities. Such taxes have traditionally included carbon taxes. More recently, the policy debate has also focused on "financial pollution" (excessive risk taking by the financial sector that could lead to crises and related externalities) and the related need to raise financial sector taxation. While some have argued for taxing financial transactions, we see merit in taxing the sector's value added (IMF, 2010b).

\footnotetext{
${ }^{10}$ See OECD (2010).
} 
- $\quad$ Taxing property, particularly real estate, can prove to be beneficial as taxing less movable tax bases is less distortionary.

- $\quad$ Fighting tax evasion more vigorously would be important both from an equity perspective and also as a way to reduce the distortion between activities in which evasion is easier and activities where it is more difficult.

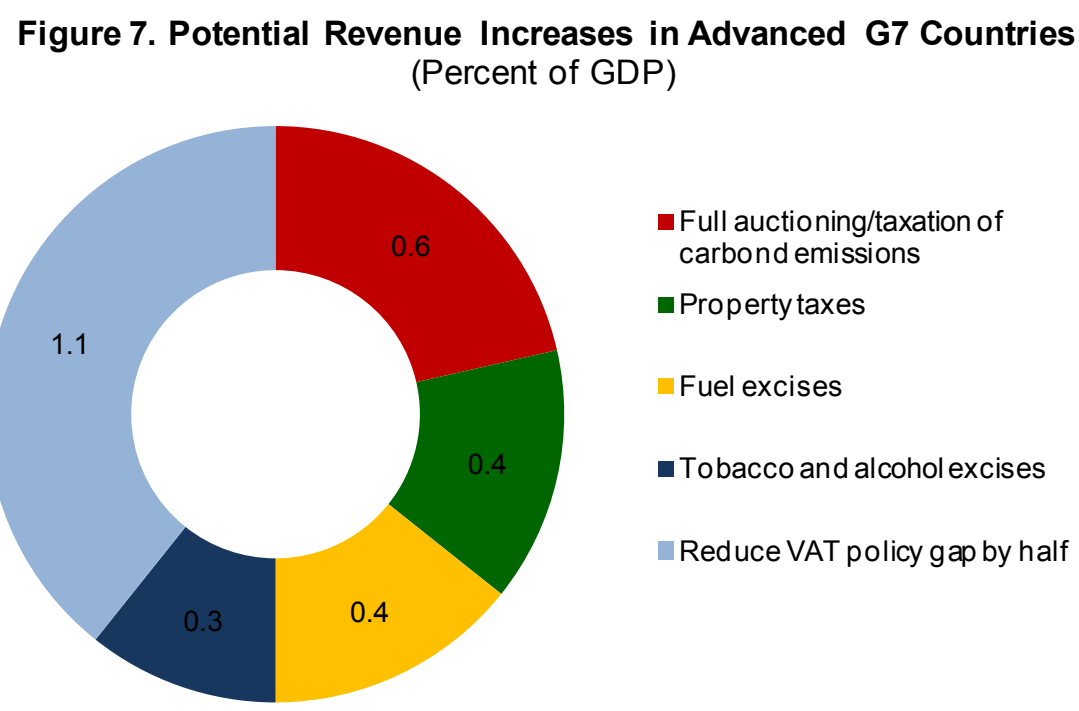

Source: IMF staff calculations

Note: PPP GDP weighted average. Total increase in revenue is 2.8 percent of GDP

On the expenditure side, across-the-board spending cuts are not conducive to durable fiscal adjustment and to growth. Spending reviews - as in the United Kingdom for exampleshould be used to identify successful spending programs to be protected, and those that are not working and to be slashed. While the proper spending mix is necessarily country specific — including the assessment of the right level of public investment - it is possible to identify some sources of spending that should be subject to particular scrutiny. These include:

- $\quad$ Subsidies of various kinds, such as agricultural subsidies that average about 1 percent of GDP in OECD member countries, and rise to 2 percent or more in Austria, Belgium, Denmark and Switzerland.

- Military spending, which has increased by almost 1 percentage point of GDP in the average of advanced countries since 2000 .

- $\quad$ Spending for public sector wages, which has increased faster than GDP in the ten years before the crisis in several advanced countries (Figure 8).

- Social welfare programs that are not means tested. Among OECD member countries, less than 10 percent of this spending is means tested. 
Figure 8. Public Sector Wages in

Selected G7 Countries

(Percent of potential GDP)

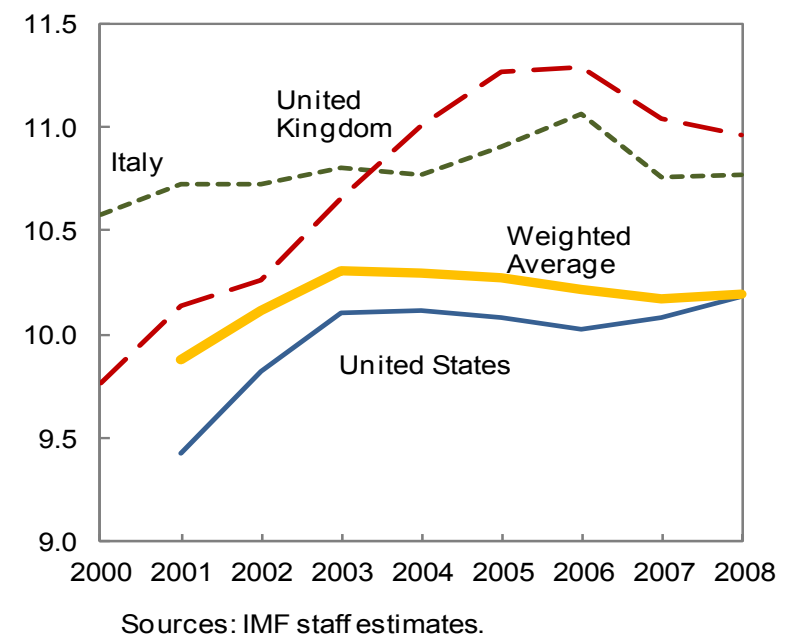

- $\quad$ Pension spending, notwithstanding the constraints imposed by demographic and other pressures. Increasing the retirement age is particularly growth-conducive as it leads to increases in the labor force over the medium term. The recent pension reform introduced in Italy is an example of improvements that allow pension spending to fall over the next twenty years (Figure 9), albeit from a very high level. It is also essential to control health care spending, which is projected to increase three times as fast as pensions over the next 20 years in the average of advanced economies. ${ }^{11}$

Figure 9. Pension Spending Increase, 2010-30



${ }^{11}$ See IMF (2010d) and IMF (2011c). 
Let us now move to the long-term effect of growth on fiscal variables. The link between fiscal sustainability and growth is further highlighted by the basic debt dynamics equation 1 below.

$$
\begin{aligned}
& d_{t}=-p_{t}+\left[1+\frac{(r-g)}{(1+g)}\right] d_{t-1} \\
& p^{*}=\frac{(r-g)}{(1+g)} d^{*}
\end{aligned}
$$

Where $d$ is the ratio of debt to GDP, $d^{*}$ is a constant debt ratio, $p$ is the primary balance to GDP, $p^{*}$ is the debt-stabilizing primary balance to GDP, $r$ is the real effective interest rate, and $g$ is the real GDP growth rate.

Solving for the debt-stabilizing primary surplus $p^{*}$ (equation 2 ), the primary surplus needed to maintain the debt to GDP ratio constant is a decreasing function of the growth rate.

Growth is particularly important for high debt countries, as a large initial debt stock increases the debt stabilizing primary balance.

This calculation, however, underestimates the effect of economic activity on debt sustainability, as the primary balance itself is affected by growth, even in the longer run. Figure 10 shows that stronger growth is associated with higher primary balances - measured on 10-year periods to reduce cyclical effects-possibly because spending adjusts at a slower pace than revenues. ${ }^{12}$ Taking into account this relationship, Figure 11 shows the change in the debt-stabilizing primary balance (and therefore the amount of discretionary spending needed to stabilize debt) that would result from a one percentage point decline in potential growth for different levels of the debt-to-GDP ratio. If a country's potential growth were to fall by 1 percentage point, with a debt ratio of 100 percent of GDP, its $p^{*}$ would have to rise by 1.7 percent of GDP (compared to 1 percent if the long-term effect of growth on the primary balance were not taken into account). Indeed, if a country were able to increase its potential GDP growth rate, it could set in motion a virtuous circle: an improvement in the potential growth rate would lower debt-to-GDP through its combined effects on the primary balance and on the interest rate-growth differential, and lower debt-to-GDP would in turn have a positive impact on potential growth.

\footnotetext{
${ }^{12}$ Empirical evidence of the positive relationship between growth and the government deficit is also found by Roubini and Sachs (1989), Edin and Ohlsson (1991), Woo (2003), and Bayar and Smeets (2009).
} 
Figure 10. Long-term Average of Primary Balance and Real GDP Growth (Percent of GDP)

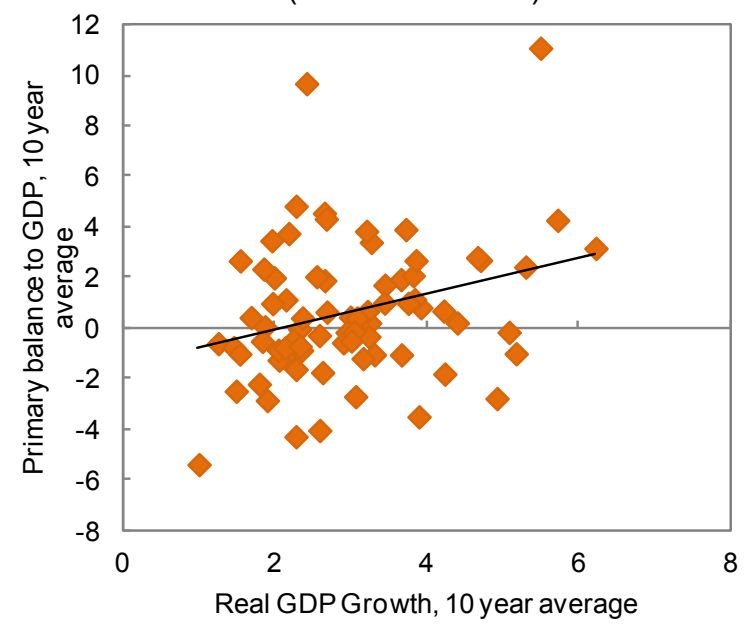

Source: IMF Fiscal Monitor, authors' calculations. Note: Average over each decade between 1970-2007.
Figure 11. Effect of Growth on Debt Stabilizing Primary Surplus (Percent of GDP)

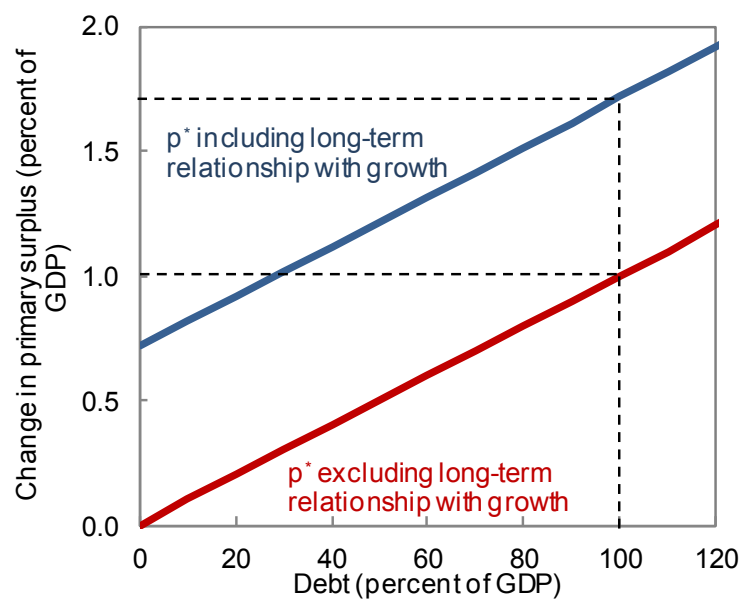

Source: Authors' calculations. Note: Effect of a one percentage point declinein potential GDP on the debt-stabilizing primary balance $\left(p^{*}\right)$, assuming an interest rate-growth differential of 1 .

History confirms that fiscal adjustment rarely occurs without healthy economic growth. In the post-World-War-II period, there have been 35 episodes in which the debt to GDP ratio was continuously reduced in advanced economies by at least 10 percent of GDP cumulatively. Of these, only one case (Italy between 1994 and 2004) occurred with real GDP growth below 2 percent. Historical data also confirm that growth does not simply matter through the denominator in the debt ratio, but also has an impact on governments' ability to deliver lasting improvements in the fiscal position, even controlling for the state of the economic cycle. In the post-war era, there were 60 instances in which advanced economies improved their cyclically adjusted primary fiscal balance continuously over three or more years; of these, only a handful occurred with growth below 2 percent.

\section{Policy Conclusions}

Several policy implications stem from the above analysis on the feedback loops between fiscal policy and growth.

First, the fiscal adjustment strategy needs to take into account the negative impact on shortterm growth that a fiscal tightening is likely to have. At least in current market conditions, fiscal adjustment at a steady pace (for countries that are not under immediate market pressure) has some advantages with respect to a front-loaded adjustment. While insufficient tightening could erode credibility, frontloaded adjustment could involve sizable output losses, and could be even counterproductive in terms of market perception and political 
economy considerations. ${ }^{13}$ Therefore, what matters to protect credibility is to ensure steady progress of fiscal consolidation. The pace at which, on average, advanced economies have adjusted their fiscal accounts in 2011-12 (about 1 percentage point per year) seems to strike the right balance between the need to consolidate the fiscal accounts and the need to avoid an excessively fast withdrawal of fiscal stimulus in the economy. Of course, country circumstances should affect the specific pace of adjustment. Other polices should be used to minimize the impact on growth of fiscal tightening. Monetary policy (through both conventional and nonconventional tools) should remain supportive of aggregate demand, as long as fiscal adjustment continues. Financial sector policies should be used to facilitate the recapitalization of banks and re-activate the credit channel; and structural policies should boost productivity and employment growth over the medium term.

Second, to ensure that gradual fiscal adjustment is not mistaken for lack of fiscal commitment, countries should define clear medium-term adjustment plans that anchor the evolution of public finances over the medium term.

Third, countries subject to market pressures have little choice but to undertake frontloaded fiscal adjustment measures, due to a lack of adequate financing at reasonable rates as well as to political constraints. In these cases, and in light of the feedback loops between growth and fiscal policy discussed above, it is particularly important that fiscal consolidation be accompanied by the availability of adequate financing to provide confidence and help keep financing costs down until the effects of the adjustment on the fiscal accounts materialize. The recent strengthening of European and global firewalls is particularly useful in this perspective.

Fourth, government debt in advanced economies needs to be lowered over time-as stabilizing debt to GDP at current elevated levels would penalize potential growth in advanced economies.

Fifth, reforms in goods, service, and labor markets will be critical in boosting potential output growth, and hence in supporting long-term fiscal consolidation. Consistently, countries need to take into account economic efficiency implications when identifying the structural fiscal adjustment reforms. Not all measures are equally beneficial. On the revenue side, there is a need to reduce tax expenditure, fight evasion, reduce the taxation of labor with respect to consumption, and increase property taxation. On the expenditure side, non-targeted

\footnotetext{
${ }^{13}$ Political considerations are often used to justify front-loading fiscal adjustment, the rationale being that gradual adjustment is more prone to being derailed sooner or later. "Just do it" has been for some time the standard policy prescription. The nonlinearities discussed above provide instead a justification for proceeding at a steady pace, including from a political economy perspective. Some gradualism in implementing the fiscal exit strategy in the current circumstances has been made also by others, albeit using different arguments (see De Long and Summers, 2012).
} 
social spending, subsidies, and military spending are good examples of possible candidates for cuts. Equity considerations cannot be disregarded, as growth that benefits only a few is not sustainable.

With the proper policies, the deep links between potential growth and fiscal policy could promote a virtuous circle in which pro-growth fiscal adjustment measures, other structural reforms, and lower debt boost growth and the latter facilitates fiscal adjustment. If this virtuous circle is activated, bringing government debt back to where it was before the crisis, at below 60 percent of GDP, no longer seems an impossible task. 


\section{Appendix. Short-run Determinants of CDS Spreads in Advanced Economies}

\section{Introduction}

Since the global financial crisis and ensuing sovereign crisis in Europe, financial markets ${ }^{\text {c }}$ assessment of credit risk for advanced economies has changed significantly. Before the crisis, the valuation of advanced economy sovereign debt treated default as a very low probability event, and therefore liquidity risk rather than default risk was seen as the dominant driver of financing costs in advanced economies. However, as the recent crisis in Europe unfolded, assessment of credit risk came to the forefront, taking into account country-specific fundamentals. In response, several countries have made progress in adopting fiscal consolidation plans, although this has not always been met with a reduction in sovereign spreads. The current crisis has shown that while markets are concerned with large debt and fiscal deficits, they also worry about low growth and its effect on debt dynamics, as wells as the feasibility of fiscal adjustment in an environment of very weak economic activity.

While a few studies have looked at sovereign spreads in advanced economies since the onset of the global crisis, we focus here on credit default swap (CDS) spreads in advanced economies during 2011, the height of the euro area crisis. Under the assumption that underlying global factors (such as global risk aversion) are behind general co-movements of CDS spreads, our analysis seeks to identify the set of country specific factors that explain the divergence of spreads across countries during the most recent phase of the global crisis. The results highlight the current short-termism of markets, which makes fiscal policy management more difficult. ${ }^{14}$ In particular, it shows that lower debt and deficit to GDP ratios lead to lower CDS spreads, but so too does faster short-term growth. There is further evidence of a nonlinear relationship between growth and sovereign bond spreads: spreads are more likely to increase if growth declines from an already low rate and the fiscal tightening is large. If growth deteriorates enough as a result of a fiscal tightening, spreads could actually rise even as the deficit falls.

\section{Background}

As fiscal fundamentals have become a growing concern of financial markets, the sovereign CDS market for advanced economies has become increasingly large. ${ }^{15}$ Several European

\footnotetext{
${ }^{14}$ Haldane and Davies (2011) provide empirical evidence of short-termism (the excess discounting of future outcomes) in equity markets, and also show that this myopia appears to be rising.

${ }^{15}$ Sovereign CDS contracts function as insurance contracts that allow investors to buy protection against the event that a sovereign defaults on or restructures its debt. Although CDS spreads generally approximate the spreads of the underlying bonds, there are several reasons why the two need not be identical. For example, there can be bond- or contract specific liquidity effects that create time-varying differences or basis risk between CDS and sovereign bond spreads (see Duffie and Singleton, 2003; Longstaff, Mithal, and Neis, 2005).
} 
advanced economies are now among the ten largest single name CDS exposures by net notional position (Figure A1), and since September 2009 investors can trade index products on a basket of Western European sovereign CDS. ${ }^{16}$ With rising size and liquidity, sovereign CDS spreads now provide more reliable signaling of sovereign credit risk.

The literature on the determinants of CDS spreads in advanced economies since the onset of the financial crisistypically focusing on a narrow set of countries and using data only through 2010 - has highlighted the importance of global factors with an increasingly prominent role of country-specific factors as the crisis progressed. Longstaff et al. (2011) show that sovereign credit risk can be linked to global factors, based on a dataset of 28 advanced and emerging economies over the period October 2000-January 2010. Similarly, Fontana and Scheicher (2010) find that the recent repricing of
Figure A1. Net Notional Positions of Sovereign Credit Default Swaps, March 2012 (Billions of USD equivalent)

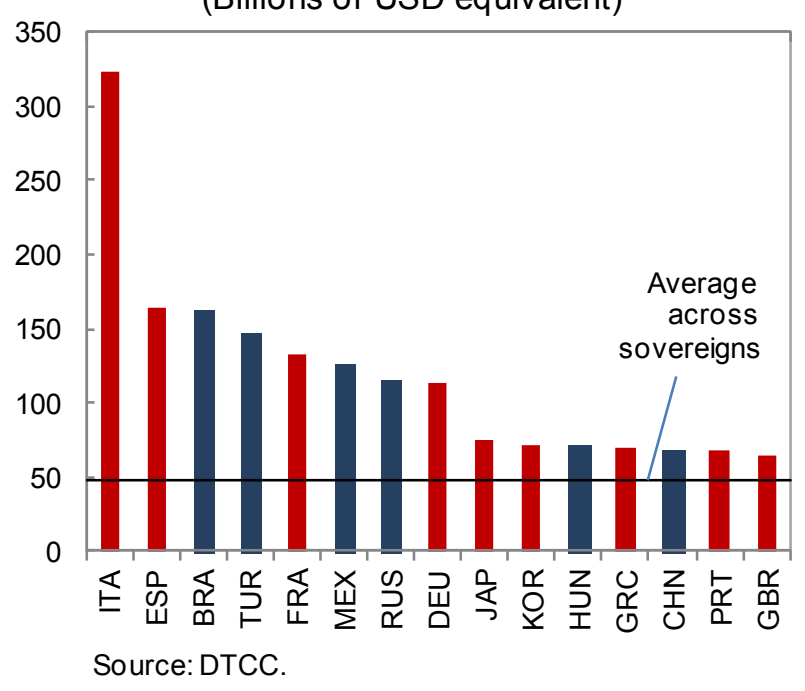
sovereign credit risk in the CDS market is mostly due to common factors. Dieckmann and Plank (2011) find - for a group of 18 advanced economies between January 2007 and April 2010 - that the state of the world financial system as well as a country's domestic financial system has strong explanatory power for the behavior of CDS spreads, with euro area countries especially sensitive. Forni et al. (2012) find that domestic financial and global factors explain movements in CDS spreads, using a panel dataset of 21 advanced economies over the period January 2008-October 2010.

As the crisis has progressed, differentiation across sovereign CDS spreads has increased significantly (Figure A2), underscoring that markets are reassessing the effect of country specific-factors on default risk. This implies that looking at historical correlations can overshadow some of the important relationships that have emerged as the crisis has evolved. In this context, this appendix attempts to shed light on the particular state of the markets in 2011, at the height of the euro area crisis.

\footnotetext{
${ }^{16}$ For further information on Markit iTraxx SovX Western European Index see http://www.markit.com/assets/en/docs/commentary/credit-wrap/SovX.pdf.
} 


\section{Figure A2. CDS Spreads and Sovereign Credit Ratings}



Sources: Markit, Fitch Ratings; Moody's Analytics, Standard \& Poor's; and IMF staff calculations. 1 Sovereign credit ratings and outlooks from Fitch Ratings, Moody's Investor Services, and Standard \& Poor's are converted into a linear scale, then averaged across the three agencies, with AAA equal to 1 and Bequal to 16 ; data as of end-2011.

\section{Empirical Model Estimation}

Sovereign CDS spreads in several European countries reached historical highs during 2011. High deficits and debt to GDP ratios have typically been a precondition for such a surge, as countries that saw their overall deficit to GDP ratio rise into the double digits or a sizeable increase in their stock of debt faced increasing market pressure (mostly in the euro area). However, there are several indications that other elements beyond fiscal fundamentals were at play. First, countries that announced sizeable fiscal adjustment plans in 2011 were not necessarily greeted with a reduction in spreads (Figure A3). Second, countries with weak fiscal accounts (such as Japan, the United Kingdom, and the United States) did not pay high spreads in 2011, which could in part be attributed to the effects of quantitative easing strategies by central banks in these countries (Figure A4). ${ }^{17}$

\footnotetext{
${ }^{17}$ See Krishnamurthy and Vissing-Jorgensen (2011) for analysis of the effects of recent quantitative easing strategies in the U.S. on interest rates.
} 
Figure A3. Additional Fiscal Consolidation and CDS Spreads

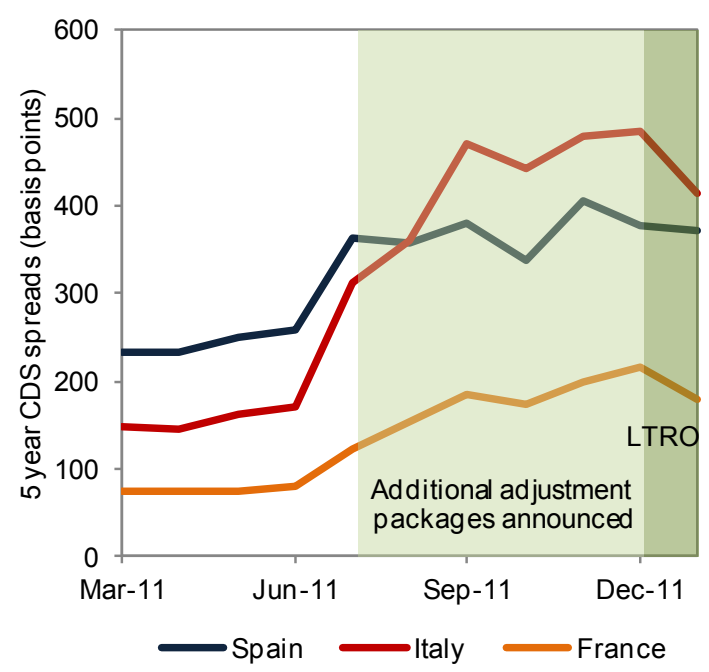

Sources: Fiscal Monitor, Markit.

Note: LTRO: Long-term refinancing operations by the European Central Bank.
Figure A4. Advanced Economies: General Government Deficit and Debt, 2011

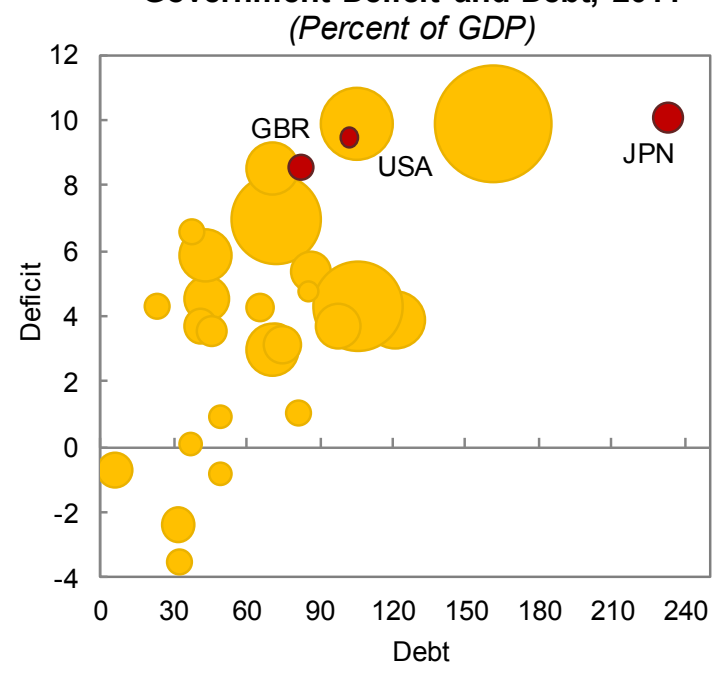

Sources: Markit; and IMF staff estimates and projections. Note: Bubble size rep resents five-year credit default swap spreads as of December 2011.

With this in mind, this appendix assesses in a more consistent way why 5-year CDS spreads differ across a sample of 31 advanced economies, ${ }^{18}$ by looking at a set of macroeconomic and fiscal fundamentals, based on a simple OLS cross-section regression. A cross-section analysis is preferred to a panel regression given the desired focus on market behavior in the latest phase of the crisis. In particular, a cross-section allows for a larger number of countries to be included, which adds greater variation to the dataset than does the time dimension (as this analysis covers only one crisis episode).${ }^{19}$ CDS spreads (average for 2011) are drawn from Markit ${ }^{20}$ and transformed into logs in line with Edwards (1984). Fiscal variables used as regressors are drawn from the September 2011 Fiscal Monitor (IMF 2011a), while macroeconomic variables are drawn from the September 2011 World Economic Outlook (IMF 2011b). Regressors include:

\footnotetext{
${ }^{18}$ The country sample includes Australia, Austria, Belgium, Canada, Cyprus, Czech Republic, Denmark, Estonia, Finland, France, Germany, Greece, Hong Kong SAR, Iceland, Ireland, Israel, Italy, Japan, Korea, Malta, Netherlands, New Zealand, Norway, Portugal, Slovak Republic, Slovenia, Spain, Sweden, Switzerland, United Kingdom, and United States.

${ }^{19}$ The results of the analysis hold even when relying on a panel framework. A Hausman-Taylor panel estimation for 16 countries (a smaller sample than the cross-section analysis due to data constraints regarding higher frequency fiscal data) based on quarterly data for 2010-11 using the same set of determinants (controlling for global factors) yielded similar results in terms of the sign and significance of the coefficients.

${ }^{20} \mathrm{CDS}$ spreads correspond to mid quotes of actively traded CDS contracts. All quotes are based on the USDdenominated CDS contract. For the United States, the Euro-denominated CDS contract is used.
} 
- Macroeconomic variables: real GDP growth rate and growth squared; projected real GDP in 2014; projected potential real GDP growth, averaged over 2011-16; inflation rate for 2011.

- $\quad$ Near-term fiscal variables: General government primary balance and general government debt as a ratio to GDP. For Australia, Canada, and Japan, net debt to GDP is used, in view of the sizeable amount of their assets.

- $\quad$ Long-term fiscal variables: Net present value of the increase in public pension spending during 2010-50 as a ratio to GDP (from IMF, 2010c); net present value of the increase in public health care spending during 2010-50 as a ratio to GDP (from IMF, 2010d); projected primary balance to GDP in 2014; projected debt to GDP in 2014.

- Investor base: General government debt of the country in question held by its national central bank (from the IMF International Financial Statistics) and, in the case of Japan, the U.K. and the U.S., by foreign central banks, based on the latest available data. $^{21}$

\section{Estimation Results}

Table A1 provides the results of the model. Column 1 reports a general specification in which all variables are included. The following columns illustrate the specification search, with insignificant variables dropped one by one. Column 5, the preferred specification, provides a relatively good fit with an adjusted R-squared of 0.76 . The results illustrate the current short-termism of markets:

- $\quad$ Fiscal variables are important, with markets focusing primarily on short-term developments (the projected primary deficit and debt in 2011). The primary balance is only significant for euro area countries. The coefficients on deficits and debt are broadly in line with what has been found by previous econometric work, though at the lower end of the range. ${ }^{22}$ For a country with CDS spreads of 200 basis points, a 1 percentage point increase in the debt ratio raises the spread by about 3 basis points and a 1 percentage point increase in the deficit raises the spread by 35 basis points. Given the log-linear specification, the larger the initial level of the CDS spread, the larger the impact on spreads, in basis points, of an increase in deficit and debt ratios;

\footnotetext{
${ }^{21}$ For the United Kingdom and United States, foreign official holdings data is from national sources. For Japan, values are estimated based on the COFER database.

${ }^{22}$ See Baldacci and Kumar (2010).
} 
consistently, a weakening of fiscal variables has a more negative impact in countries with higher initial deficit and debt ratios.

- $\quad$ Long-term fiscal variables are not found to be significant. The coefficients on future debt and deficits and on public pension and health spending were not found to be significant. This suggests that reforms to entitlement spending or measures that would only have a long term impact would not necessarily be rewarded by markets in the short run. This result underscores the difficulty of providing credible information to markets in this area and the need for more effective communication of the effect of such reforms on the soundness of public finances.

- $\quad$ Short-term growth is important (higher growth leading to lower spreads), while potential growth and future growth are not significant. This relationship is found to be nonlinear - with a positive coefficient on the squared growth term — as spreads are more likely to increase when growth is already low and fiscal tightening is larger. ${ }^{23}$ Based on these results, if the fiscal multiplier is sufficiently large (higher than 0.7 based on the estimated coefficients), the improvement in spreads from a lower deficit could be offset by the negative impact of adjustment on short-term growth, which also acts through the short-term rise in the debt to GDP ratio (see Figure 5 in the main text).

- $\quad$ Central bank financing (either from national central banks or from foreign central banks) is important in lowering spreads, as long as it is not inflationary. This coefficient is higher than the one on the debt ratio, implying that the effect of purchases by national central banks (and by foreign central banks for reserve currencies) goes beyond the effect of reducing the overall supply of government bonds sold to the public. This probably reflects confidence effects provided by the presence of the central bank in the market. Note, however, that the central bank holdings variable does not include purchases by the ECB through the Securities Market Program. ${ }^{24}$ The coefficient for inflation is highly significant, and thus implies that central bank purchases are effective in moderating spreads only if they are not inflationary. Given the large accumulation of excess reserves by banks, inflation

\footnotetext{
${ }^{23}$ It should be noted that, based on these coefficients, a decline in growth for countries with initial growth rates above 5 percent would reduce spreads. However, the country sample used for the analysis does not include countries with these growth rates, and these high growth rates are unlikely to be observed in advanced economies.

${ }^{24}$ When these were included separately, they appeared with positive sign and when added as part of central bank holdings (national and foreign) the significance of the variable declined. This may be due to measurement problems, as the ECB does not publish its purchases country-by-country so market estimates were used. It may also mean that purchases that are not conducted transparently (at the country level) are not very effective. The positive sign may also reflect simultaneity problems, with the ECB purchasing sovereign bonds of countries already under intense market pressure.
} 
pressures currently remain at bay in most countries. The respite in sovereign bond markets, following the long-term refinancing operations (LTRO) of the European Central Bank (ECB) are a further example of the confidence effects of central bank intervention. These results suggest that the availability of financing from an entity with sufficiently large resources could help reduce spreads in the current environment.

\section{Conclusions}

The cross-section estimates point to the current short-term vision of markets, with special concern for near-term growth prospects. This could possibly reflect strong risk aversion after four years of market turmoil. These results imply that tighter fiscal policy could actually lead to wider, rather than narrower, spreads in the short term. It is important to note, however, that the euro area crisis is still not fully resolved and financial markets remain unsettled, therefore these results may reflect the particular state of markets in 2011 rather than more permanent features, something that a cross section cannot shed light on. Moreover, it would be important to assess the direct effect on spreads of other variables beyond fiscal fundamentals, such as exposure to contingent liabilities from the banking sector. Potential simultaneity issues (e.g., between spreads and growth) also deserve additional attention. 
Table A1. Determinants of CDS Spreads in Advanced Economies, Cross Section Analysis 2011

\begin{tabular}{|c|c|c|c|c|c|}
\hline & (1) & $(2)$ & (3) & $(4)$ & (5) \\
\hline Gross debt to GDP 2011 & $\begin{array}{l}0.0124^{* *} \\
(2.735)\end{array}$ & $\begin{array}{l}0.0126^{* *} \\
(2.773)\end{array}$ & $\begin{array}{l}0.0120^{* * *} \\
(2.848)\end{array}$ & $\begin{array}{l}0.0120^{* * *} \\
(2.844)\end{array}$ & $\begin{array}{c}0.0122^{* * *} \\
(2.931)\end{array}$ \\
\hline $\begin{array}{l}\text { Primary balance to GDP } 2011 \\
\text { for Euro Area }\end{array}$ & $\begin{array}{l}-0.172^{\star \star \star} \\
(-3.581)\end{array}$ & $\begin{array}{l}-0.177^{\star \star \star} \\
(-3.661)\end{array}$ & $\begin{array}{l}-0.182^{\star \star \star} \\
(-3.578)\end{array}$ & $\begin{array}{c}-0.187^{* * *} \\
(-3.602)\end{array}$ & $\begin{array}{c}-0.194^{* * *} \\
(-3.800)\end{array}$ \\
\hline Real GDP growth 2011 & $\begin{array}{l}-0.210^{* \star} \\
(-2.208)\end{array}$ & $\begin{array}{l}-0.241^{* * *} \\
(-3.502)\end{array}$ & $\begin{array}{l}-0.242^{\star * *} \\
(-3.631)\end{array}$ & $\begin{array}{l}-0.239^{* * *} \\
(-3.699)\end{array}$ & $\begin{array}{c}-0.230^{* * *} \\
(-3.860)\end{array}$ \\
\hline Real GDP growth squared & $\begin{array}{c}0.0359^{* *} \\
(2.786)\end{array}$ & $\begin{array}{c}0.0348^{* *} \\
(2.495)\end{array}$ & $\begin{array}{c}0.0342^{* *} \\
(2.554)\end{array}$ & $\begin{array}{l}0.0327^{* *} \\
(2.577)\end{array}$ & $\begin{array}{c}0.0323^{* *} \\
(2.545)\end{array}$ \\
\hline $\begin{array}{l}\text { Debt held by a country's central bank or } \\
\text { by foreign central banks to GDP }\end{array}$ & $\begin{array}{l}-0.0261 \\
(-1.157)\end{array}$ & $\begin{array}{l}-0.0248 \\
(-1.078)\end{array}$ & $\begin{array}{l}-0.0205 \\
(-1.185)\end{array}$ & $\begin{array}{l}-0.0222 \\
(-1.348)\end{array}$ & $\begin{array}{r}-0.0272^{*} \\
(-1.842)\end{array}$ \\
\hline Inflation rate 2011 & $\begin{array}{l}0.263^{* *} \\
(2.659)\end{array}$ & $\begin{array}{l}0.255^{\star *} \\
(2.566)\end{array}$ & $\begin{array}{c}0.241^{* * *} \\
(2.935)\end{array}$ & $\begin{array}{l}0.244^{* * *} \\
(3.113)\end{array}$ & $\begin{array}{c}0.222^{* * *} \\
(2.907)\end{array}$ \\
\hline NPV of health spending to GDP 2010 & $\begin{array}{c}-0.00165 \\
(-0.508)\end{array}$ & $\begin{array}{c}-0.00200 \\
(-0.668)\end{array}$ & $\begin{array}{c}-0.00229 \\
(-0.868)\end{array}$ & $\begin{array}{c}-0.00196 \\
(-0.766)\end{array}$ & \\
\hline NPV of pension spending to GDP 2010 & $\begin{array}{c}0.00174 \\
(0.422)\end{array}$ & $\begin{array}{c}0.00124 \\
(0.307)\end{array}$ & $\begin{array}{c}0.00111 \\
(0.265)\end{array}$ & & \\
\hline $\begin{array}{l}\text { Primary balance to GDP } 2014 \\
\text { for Euro Area }\end{array}$ & $\begin{array}{l}-0.0290 \\
(-0.444)\end{array}$ & $\begin{array}{l}-0.0208 \\
(-0.307)\end{array}$ & & & \\
\hline $\begin{array}{l}\text { Potential output growth, } \\
\text { average 2011-2016 }\end{array}$ & $\begin{array}{l}-0.103 \\
(-0.520)\end{array}$ & & & & \\
\hline Constant & $\begin{array}{l}3.529^{* * *} \\
(6.312)\end{array}$ & $\begin{array}{l}3.485^{\star * *} \\
(6.133)\end{array}$ & $\begin{array}{l}3.551^{* * *} \\
(6.805)\end{array}$ & $\begin{array}{l}3.576^{\star * *} \\
(7.030)\end{array}$ & $\begin{array}{c}3.490^{* * *} \\
(7.495)\end{array}$ \\
\hline Observations & 31 & 31 & 31 & 31 & 31 \\
\hline R-squared & 0.769 & 0.765 & 0.764 & 0.763 & 0.760 \\
\hline
\end{tabular}

Robust t-statistics in parentheses

${ }^{* * *} p<0.01,{ }^{* *} p<0.05,{ }^{*} p<0.1$ 


\section{References}

Alesina, A. and R. Perotti, 1996, "Fiscal Adjustments in OECD Countries: Composition and Macroeconomic Effects,” NBER Working Paper No. 5730.

Alesina, A. and S. Ardagna, 2009, "Large changes in fiscal policy: taxes versus Spending," NBER Working Paper No. 15438.

Alper, C. Emre, Lorenzo Forni and Marc Gerard, 2012, "Pricing of Sovereign Credit Risk: Evidence from Advanced Economies During the Financial Crisis," IMF Working Paper No. 12/24.

Baldacci, E., S. Gupta, and C. Mulas-Granados, 2012, "Reassessing the Fiscal Mix for Successful Debt Reduction," Economic Policy (accepted, forthcoming April 2012).

Baldacci, E. and M. Kumar, 2010, "Fiscal Deficits, Public Debt, and Sovereign Bond Yields," IMF Working Paper No. 10/184.

Baum, A., M. Poplawski-Ribeiro and A. Weber, 2012, "Fiscal Multipliers and the State of the Economy," IMF Working Paper (forthcoming; Washington: International Monetary Fund).

Bayar, A. and B. Smeets, 2009, "Economic and Political Determinants of Budget Deficits in the European Union: A Dynamic Random Coefficient Approach," CESifo Working Paper No. 2546.

Berg, A. and J. Ostry, 2011, "Inequality and Unsustainable Growth: Two Sides of the Same Coin?” IMF Staff Discussion Note 11/08.

Bertola, G. and A. Drazen, 1993, "Trigger Points and Budget Cuts: Explaining the Effects of Fiscal Austerity," American Economic Review, 83, pp. 1170-1188.

Caceres, C., V. Guzzo, M. Segoviano, 2010, "Sovereign Spreads: Global Risk Aversion, Contagion or Fundamentals?" IMF Working Paper No. 10/120.

Cecchetti, S. G., M. S. Mohanty and F. Zampolli, 2011, “The Real Effects of Debt,” BIS Working Paper No. 352.

DeLong, J.B., and L. Summers (2012), "Fiscal Policy in a Depressed Economy," Spring 2012 Conference on the Brookings Papers on Economic Activity (BPEA), available at http://www.brookings.edu/ /media/Files/Programs/ES/BPEA/2012_spring_bpea_papers/201 2_spring_BPEA_delongsummers.pdf

De Mooij, R. and M. Keen, 2012, "Fiscal Devaluation and Fiscal Consolidation: the VAT in Troubled Times,” NBER Working Paper No. 17913. 
Dieckmann, S. and T. Plank, 2011, "Default Risk of Advanced Economies: An Empirical Analysis of Credit Default Swaps during the Financial Crisis," Working Paper, Available at http://ssrn.com/abstract $=1572118$

Dolls, M., C. Fuest, and A. Peichl, 2010, "Automatic Stabilizers and Economic Crisis: U.S. vs. Europe,” NBER Working Paper No. 16275.

Duffie, D. and K.J. Singleton, 2003, Credit Risk: Pricing, Measurement, and Management. Princeton: Princeton University Press.

Edin, P. and H. Ohlsson, 1991, "Political Determinants of Budget Deficits: Coalition Effects Versus Minority Effects," European Economic Review 35, p. 1597-1603.

Edwards, S., 1984, "LDC's Foreign Borrowing and Default Risk: An Empirical Investigation 1976-1980," NBER Working Paper No. 1172.

Escolano, J., 2010, “A Practical Guide to Public Debt Dynamics, Fiscal Sustainability, and Cyclical Adjustment of Budgetary Aggregates," IMF Technical Notes and Manuals.

Eyraud, L. and A. Weber, 2012, "Debt Reduction during Fiscal Consolidation: The Role of Fiscal Multipliers", unpublished manuscript.

Feldstein, M., 2002, “Commentary: Is There a Role for Discretionary Fiscal Policy?” Federal Reserve Bank of Kansas City Economic Policy Symposium, pp. 151-62.

Fontana, A. and M. Scheicher, 2010, "An Analysis of Euro Area Sovereign CDS and Their Relation with Government Bonds," ECB Working Paper Series No. 1271.

Haldane, R. and R. Davies, 2011, “The Short Long," speech at the 29th Société Universitaire Europ ene de Recherches Financi res Colloquium: New Paradigms in Money and Finance, Brussels May 2011, available at http://www.bankofengland.co.uk/publications/speeches/2011/speech495.pdf

Hall, P., ed., 1989, "The Political Power of Economic Ideas: Keynesianism Across Nations," (Princeton: Princeton University Press).

Haugh, D., P. Ollivaud and D. Turner, 2009, "What Drives Sovereign Risk Premiums? An Analysis of Recent Evidence from the Euro Area," OECD Economics Department Working Papers No. 718.

International Monetary Fund, 2010a, World Economic Outlook, October (Washington: International Monetary Fund).

, 2010b, "A Fair and Substantial Contribution by the Financial Sector: Final Report for the G-20," IMF Staff Paper (Washington: International Monetary Fund). Available via the Internet: http://www.imf.org/external/np/g20/pdf/062710b.pdf. 
,2010c, "From Stimulus to Consolidation: Revenue and Expenditure Policies in Advanced and Emerging Economies," IMF Staff Paper 10/64 (Washington: International Monetary Fund).

,2010d, "Macro-Fiscal Implications of Health Care Reforms in Advanced and Emerging Economies,” IMF Policy Paper (Washington: International Monetary Fund).

,2011a, Fiscal Monitor-Addressing Fiscal Challenges to Reduce Economic Risks, (Washington: International Monetary Fund).

,2011b, World Economic Outlook, September, (Washington: International Monetary Fund).

, 2011c, "The Challenge of Public Pension Reform in Advanced and Emerging Economies”, IMF Policy Paper, December 28. (Washington: International Monetary Fund). Fund).

,2012a, Fiscal Monitor Update, January (Washington: International Monetary

,2012b, Fiscal Monitor_Balancing Fiscal Policy Risks (Washington: International Monetary Fund).

Krishnamurthy, A. and A. Vissing-Jorgensen, 2011, "The Effects of Quantitative Easing on Interest Rates: Channels and Implications for Policy," NBER Working Paper No. 17555.

Kumar, M., and J. Woo, 2010, "Public Debt and Growth,” IMF Working Paper No. 10/174.

Longstaff, F., S. Mithal, and E. Neis, 2005, “Corporate Yield Spreads: Default Risk or Liquidity? New Evidence from the Credit Default Swap Market," The Journal of Finance, Vol. LX, No. 5.

Longstaff, F., J. Pan, L.H. Pedersen, and K. J. Singleton, 2011, “How Sovereign is Sovereign Credit Risk?” American Economic Journal: Macroeconomics, 3, pp.75-103.

Organization for Economic Cooperation and Development, 2010, “Tax Policy Reform and Economic Growth,” OECD Tax Policy Studies No. 20.

Panizza, Ugo and Andrea F. Presbitero, 2012, "Public debt and economic growth: Is there a causal effect?" POLIS Working Papers 168, Institute of Public Policy and Public Choice POLIS.

Perotti, R., 1999, "Fiscal Policy in Good Times and Bad," Quarterly Journal of Economics, 114, pp. 1399-1436. 
Perotti, R., 2011, “The 'Austerity Myth': Gain Without Pain?” NBER Working Paper No. 17571, November.

Reinhart, C. and K. Rogoff, 2010, "Growth in a Time of Debt," NBER Working Paper No. 15639 .

Roubini, N. and J. Sachs, 1989, "Political and Economic Determinants of Budget Deficits in the Industrial Democracies," European Economic Review, 33, pp. 903-938.

Schuknecht, L., J. von Hagen and G. Wolswijk, 2010, "Government Bond Risk Premiums in the EU Revisited: The Impact of the Financial Crisis," ECB Working paper No. 1152.

Sgherri, S. and E. Zoli, 2009, "Euro Area Sovereign Risk During the Crisis," IMF Working Paper No. 09/222.

Sutherland, A., 1997, "Fiscal Crises and Aggregate Demand: Can High Public Debt Reverse the Effects of Fiscal Policy?" Journal of Public Economics, 65, pp. 147-162.

Woo, J., 2003, "Economic, Political, and Institutional Determinants of Public Deficits," Journal of Public Economics, 87, pp. 387-426. 